Wacana, Vol. 7 No. 1 (April 2005): 97-110

\title{
Islam, the Indonesian state, and identity The ideas of Nurcholis Madjid and Abdurrahman Wahid
}

\author{
MUHAMMAD FUAD
}

\begin{abstract}
Makalah ini membahas gagasan-gagasan Nurcholis Madjid dan Abdurrahman Wahid tentang hubungan antara Islam dan negara dan antara Islam dan bangsa dan implikasinya pada konsep tentang identitas Muslim di Indonesia. Madjid berpendapat bahwa umat Islam pernah berhasil mengembangkan masyarakat yang demokratis pada masa Madinah dan Andalusia di masa lampau. Dia mengajak umat Islam Indonesia untuk menggunakan keberhasilan ini sebagai model untuk membangun demokrasi di Indonesia sekarang. Sementara itu, Wahid menelusuri sejarah Indonesia untuk mencari model tersebut dan mencoba menerapkannya pada situasi Indonesia sekarang. Implikasi dari dua orientasi yang berbeda ini adalah bahwa model Madjid mengesankan identitas Muslim yang lebih menekankan keislaman dan model Wahid mengesankan identitas yang lebih menekankan keindonesiaan.

KATA KUNCI

Islamic state, democracy, Islam, cultural politics, power politics, identity.
\end{abstract}

In this paper I would like to attempt to craft out formulations of identity out of the writings of Nurcholis Madjid and Abdurrahman Wahid. I am relying mainly on the pieces that the two writers wrote in the 1980s and early 1990s collected already in book form. For Madjid, I am using a collection titled Islam Agama Kemanusiaan: Membangun Tradisi dan Visi Baru Islam Indonesia [Islam, Religion of Humanity: Building Indonesia's New Islamic Tradition and Vision]; and for Wahid titled Mengurai Hubungan Agama dan Negara [Untying Relation between Religion and the State]. As the titles suggest, the pieces in the two collections are about Islam, the Indonesian state and the relation between the two. They, however, are also about the relation between Islam and the Indonesian nation.

MUHAMMAD FUAD, lahir di Parakan, Temanggung, Jawa Tengah (1954); adalah pengajar pada Program Studi Inggris dan Program Studi Kajian Amerika di Universitas Indonesia; anggota Departemen Sejarah di universitas tersebut; mendapat gelar magister dari Program Studi Kajian Amerika, University of Iowa, pada tahun 1993; berminat pada hubungan antara agama, modernisme, dan modernitas dalam berbagai bentuk; aktif menulis artikel, yang telah dimuat dalam jurnal nasional dan internasional

(C) 2011 Faculty of Humanities, University of Indonesia 
Needless to say, Madjid and Wahid are well known as advocates of substantive, inclusive, tolerant, and democratic Islam. They are also well known to have been concerned with developing ideas about Indonesian Islam; diligently exploring possibilities, in the Indonesian context, of relations between Islam and politics, Islam and the state ideology, the role of Islam in the project of nation building, as well as the relation of Muslims as majority with the rest of the population. My focus here is on the implications of the ideas of the two writers concerning these issues on the problem of identity. It might be proposed that discussion of the ideas of the two thinkers have been exhausted. It might also be argued that the two thinkers have matured, as thinkers, mainly in the context of the hegemony of the New Order regime that their ideas belong to the time and of little relevance to the post-New Order situation. A point could also be made that Wahid has proved himself a failure as president that whatever he thinks and has thought is irrelevant. Insofar as the thinking on the relations beween Islam and the Indonesian state and Islam and the Indonesian nation, however, no living Indonesian Muslim thinkers have surpassed their diligence, persistence, and thoroughness. None have also surpassed them in the depth of their insight into these issues. In terms of the contemporary political development of post-Suharto Indonesia, where political parties that wave the banner of Islam and foreground Islamic agenda are on the rise, the ideas of these two thinkers could not be more relevant. Besides, a juxtaposition of the ideas of the two thinkers similar to what I would like to do here has been absent. As a result, a valuable understanding of what it means to be a Muslim in Indonesia that can be gleaned out of the ideas of the two thinkers has been missing, and missed.

What one cannot escape, reading the two collections by Madjid and Wahid, is the difference in the approaches that the two thinkers employ in dealing with the issues Islam and the Indonesian state and Islam and the Indonesian nation. Madjid, a believer in the democratic success of the Islamic communities in the Madinah period and in the Spain Islamic regime of the $12^{\text {th }}$ century in dealing with plurality, appeals to Indonesian Muslims to look at the two experiences for inspiration. He believes that Indonesian Muslims, being a majority in Indonesia, can apply the experiences to deal with the Indonesian situation. Wahid, meanwhile, explores Indonesian experience in dealing with the problem of plurality, both religious and cultural, and attempts to construct a model based on that Indonesian historical experience in order to tackle contemporary problems. What emerges from Madjid's narrative is something that resembles an image of an ideal social and political model of Islamic community, based on Muslim experience in Arabia and Europe, assumed to be good for Indonesia. From Wahid's narrative, meanwhile, emerges a tentative model that grows out of Indonesian's own experience that sounds down to earth and might work for today's problems. Madjid's proposal impresses as more Islamic and Wahid's as more Indonesian. 
AN INDONESIAN ISLAM

For Madjid, Islam that has developed in Indonesia has two components, the sacred and the cultural. The sacred component is Islam the religion, which is absolute, unchanging, transcendent, and thus universal. The cultural is the expression, the form, in which Islam the religion realizes itself in terms of local culture, which is relative and historical. The two components must be distinguished at all time. Otherwise, confusion will arise, a confusion that amounts to that of, in Platonic terms, the ideal truth with its shadowy actualization in the human world. In Hegelian terms, it would a confusion of Being with Non-Being. For some Hegelian thinkers, this confusion is the mother of false consciousness. For Madjid, this confusion is one of hierarchy of values, taking the absolute to be the relative and vice versa, that can cripple humand mind. Unlike the Hegelian thinkers, however, who are suspicious of all forms they consider to be the embodiment of Non-Being, Madjid views the cultural Islam, that is Islam realized in its cultural form, as no less valuable than Islam the eternal and universal.

Madjid is not a subscriber to Hegelian thinking. He has made the distinction between the ideal and actual Islam not to deal with a philosophical problem but to work out a solution to a grave political problem. It was to break a roadblock that had politically paralyzed the ummah in Indonesia and to prevent the roadblock from reconstituting itself. This strategy, although not without its damning critics, worked. It has made many within the ummah realize that not all the things they do, including the things they claim they do for the sake of Islam, are necessarily part of the ideal and sacred Islam. They might be things necessary and good for Muslim and Islam, but they can be part of the cultural Islam. They are not, therefore, necessarily sacred and absolute, but are relative and optional. Politics, or more precisely power politics, is an important realm to be put in the category of the cultural because it has been repeatedly confused with the sacred, a confusion that has led Mulims in Indonesia to political roadblocks. Worse, the confusion of politics with the sacred by Indonesian Muslims has also blocked their mind from other realms no less important to be mined and nurtured for the betterment of their lives. This, I think, is what Madjid means when he says that the confusion of the absolute and the relative cripples human mind. He has shown, not only by words but also by example, that cultural politics can be an effective means toward the building of the ummah.

Madjid never tires of exhorting the ummat that Islam that has developed in Indonesia is no less Islamic, hence no less legitimate, than any Islam anywhere else, including Islam in the land of Arabia. He mantains that the dialogue between Islam the universal and the local space and time in Indonesia has produced extraordinarily creative tradition that has enabled the ummat to deal with the challenges of every age in history. This Islamic tradition, with the pure, ideal Islam always brought closely to bear and guiding, is what Islam in Indonesia has been and will always be. In fact, Islam in every temporality and locality of the world has developed along the same line. 
Madjid's idea of a pure universal Islam, that must be kept pure in accordance with the sunnah and Al-kitab and free of innovation, is to appease his critics and the modernist whose belief in a pure Islam is uncompromising. His assertion of the legitimacy and creative utility of the Islamic tradition is to appease the traditionalist. But the latter is also to boost the confidence of the ummat in Indonesia. Madjid, by emphasizing the legitimacy and the creativity of the Islamic tradition in Indonesia, wants the ummah to see that they can change and need to change toward the better. It is very important that they change in order to be able to deal with and participate in the process of the industrializing of Indonesia. Otherwise, they will remain marginalized.

Madjid believes that the process of change can start from the mind; that the ummat will change if they change the way they think. It is important then to teach them, especially about the treasures of the Islamic intellectual tradition. What exactly to teach to the ummah in Indonesia, naturally, also depends on the specific needs of the time. And these needs, in these last three decades, are adequate and appropriate information that will equip them to cope with modernization and modernity - industrialization, the nation state, the market, democracy - and to understand how to relate to them and their role in them. Madjid wants the ummah to know that Islam, both the transcendent and the historical, has everything. He teaches therefore that there have been times in the history of Islam where the historical Islam came close to the ideal. They happened in Madinah during the Madinah time of the Muslim community under the Prophet's leadership and in Spain in the $12^{\text {th }}$ century under the administration of the Andalusia regime. These historical Islams, in two diferent times and places, were politically democratic and tolerant and culturally modern, cosmopolitan, open, humanist, progressive, and, especially the latter, scientific. This, Madjid argues, shows that Islam has really been a blessing for the whole mankind. Europe's renaissance and religious reformation learned about the the idea of the dignity of man from their contact with Islamic culture. Madjid wants the ummah in Indonesia to know these facts. These ideal historical Islams did not materialize in Nusantara, partly because of colonization, but they can be used as reference and, ultimately, reconstructed here. He knows that a lot of hard work is required for this, but with the right understanding and action, it can be done. It is of paramount importance that the ummah in Indonesia, being the majority population, realize the possibilities of this project and their vital role in its realization. This realization would mean the realization of a modern, democractic, and industrial Indonesia where Muslims can, potentially, become sort of a hegemonic group.

Madjid's emphasis on the importance of teaching the ummah and influencing their consciousness has led him to public education as his main activities. Abdurrahman Wahid sees such activities as part of what he calls cultural-approach Islamic movement, with its emphasis on reviving Islam in Indonesia as a culture and cultural force through cultural activities. For Wahid, a more comprehensive approach would be one that he adopts and calls socio-cultural approach. In this approach, cultural activities by themselves 
are seen as inadequate to effect long-term social structural changes. They need to be accompanied by building social institutions. Muhammadiyah and Nahdlatul Ulama, in Wahid's view, exemplifies this approach. Their concern with the unfavorable social economic condition of the ummah has led them to build schools, hospitals, and other social institutions. This bias, reflected by Wahid's adoption of this approach, influences his narrative about Islam in Indonesia. What emerges out of Wahid's narrative is an organized Islam in Indonesia. It is an Islam that gets formed and transformed through and by its organizations along Indonesian history. An organized Islam is inevitably a political Islam, not in the sense that it aspires to power politics, but in the sense that it has, and able, to negotiate with the state concerning policies that affect their social programs from time to time.

The Indonesian Islam that comes out of Wahid's narrative is, in other words, a historical and contextual Islam. It is an Islam, embodied in its organized groups, that wrestles with the social problems of its adherents, like poverty and lack of education, and negotiates with different statesindigenous, colonial and post-colonial - that come and go along Indonesian history. Wahid points out that Islam itself also undergoes change in the process, as exemplified by the syncretic nature it acquires. It is, thus, an Islam that has grown in Indonesia as a native growth. Wahid is aware of the distinction between the home-grown Islam and the unchanging transcendent Islam that some people make, but he never worries about it. Nor does he worry about an ideal historical Islam outside Indonesia to be imitated or used as referene, although Islam in Indonesia has never had any experience of a golden age it can boast.

This suggests that in Wahid's view Islam that has grown and developed with Indonesia as its native locus is the main Islam that the ummah in Indonesia have. In fact, he can be very critical of Islam in the Middle East. He points out, for example, that the tendency to use Islam as a rallying point in Indonesia is a disease contracted from the Middle East. He also suggests that the fact that the ruling power in contemporary Saudi Arabia never cares to deal with the problem of poverty and ignorance of its people is an example how a regime that claims itself to be Islamic can in fact be un-Islamic.

It does not follow, however, that Wahid does not have an ideal of an Islamic society that he sees Muslims in Indonesia must strive for. His criticism of the Saudia Arabian authority suggests that bringing welfare to the people is part of his ideal. His writings reveal that his concern for people's welfare emerges as part of his greater preoccupation with justice and democracy. Before discussing the relation between Indonesian Islam and democracy in the thinking of both Madjid and Wahid, however, I should point out that the brief discussion above about their discourses on Indonesian Islam can have different implications for identity construction. Both men are equally concerned for developing discourse on Islam that has some sort of Indonesian trademark on it. Madjid's writings, however, suggest that he is concerned with a universal Islam first and Indonesian Islam second. This can further 
suggest that for Madjid being a "universal" Muslim, that is, the sense of being a Muslim that transcends the boundaries of race, culture, or nation, comes before the sense of being an Indonesian Muslim. For Wahid, meanwhile, the two should be seen as always tied together. It seems that for Wahid, being a Muslim is never unsituated to a locality. The locality, naturally, can be problematic. Wahid, however, never doubts that for the ummah in Indonesia that locality is the nation of Indonesia.

\section{ISLAM, THE INDONESIAN STATE, AND IDENTITY}

Both Madjid and Wahid are unquestioning in their support for the state of Indonesia. They are equally unquestioning in their call to the ummah to do the same. This call, of course, is also meant to fend off the arguments of those who wants an Islamic Indonesian state. A closer look reveals similarities and differences in their reasonings. They agree that there is no positive injunction in Islam about state formation. Madjid points out to the controversy between the Syi' $i$ and the Sunni schools concerning the matter. Within the Syi'i school, religious and worldly matters are seen as intertwined implying that there should be no separation between religious and political matters. Within the Sunni tradition, however, a distinction between the two realms is made. This controversy means that the idea of the intertwining of religion and politics is by no means an ideal universally accepted. In fact, within the muslim world, it is a minority view. Madjid, thus, finds a justification for his argument that politics is not always an essential part of religion within the Sunni tradition. He also applies this justification to the problem of the state where the state, being a political organization, does not have to be religious. Madjid, that is, fends off the arguments for an Indonesian Islamic state by theorizing the disengagement of state formation from religion proper.

To further call for the support of the ummah for the Indonesian state, Madjid frames his argument in an "interest logics," that is, it is in the interest of the ummah that they support the state of Indonesia. He reasons that whatever becomes of the people of Indonesia becomes of the ummah because the ummah constitutes the majority of the Indonesian population. It is in their interest to be concerned about and feel responsible for whether Indonesia develops into a prosperous advanced country or whether it remains a poor backward country. The choice, argues Madjid, is clear that Indonesia must join the modern advanced world. The stake that the ummah have makes it imperative for them to support the development program laid out by the government. They have to fashion an active role to play in the national development process. Giving a full support to the Indonesian state is a crucial role that the ummah in Indonesia can play.

Wahid, meanwhile, argues for the support of the Indonesian state by affirming that the state is an accepted and established idea within the Islamic intellectual tradition. While agreeing with Madjid that there is no Qur'anic injunction nor Sunnah example concerning state formation, Wahid argues that the formation of the state within the Islamic experience is based on the 
community's situational need. He suggests that there has never been any Islamic state in the history of Islam because after the third year of hijrah, the so-called Islamic states were governed, in practice, by sultans, or heads of government, and not by khalifahs who, in reality, were only puppets of the sultans. In other words, the so-called Islamic states in the history of Islam are actually secular states. The basic concept of society in Islam, Wahid argues, is al hukmu (law) not al-daulat (state). What is of priority is the operation of Islamic law within civil society. A state that guarantees such operation, that is, the freedom for the ummah to practice syaria, is worthy of support. Its specific form is of second priority. Wahid thus argues for the existence of a state, which, in practice, is never religious but always secular. He stresses its practical necessity and usefulness for the protection of the freedom of the ummah to practice syariah. It needs to be noted that for Wahid, syariah (Islamic law) is not a formal legal system legislated by the state, but a functioning social ethic.

For the support for the Indonesian state, Wahid buttresses the utilitarian argument with another argument along the line of figh. The Indonesian state has protected for the Indonesian ummah their right to worship and to live according to the syariah. For this reason, the Indonesian state is viewed as legal in terms of the figh system. Wahid points out that the legality of the Indonesian state has been confirmed by a recognized court of figh scholars within the tradion of Nahdlatul Ulama. This confirmation is seen to have a binding consequence on the ummah in the sense that it becomes an obligation for the ummah in Indonesia to support it. That is, the ummah are bound by an Islamic legal injunction to support the Indonesian state. A further legal consequence of the injunction is that any other state declared within the jurisdiction of the Indonesia state is seen as illegal. That is, as a further consequence of the injunction to support the Indonesian state, the ummah is bound to reject any state within the jurisdiction of Indonesia as illegal. This consequence applies regardless of the party who declares an alternative (that is illegal) state, including Muslims, and the claim on which the declaration is made, including Islam. Any declaration of an Indonesian Islamic state within the existing jurisdiction of the Indonesia state, thus, would constitute an example of such illegal declaration.

Both Madjid and Wahid therefore strongly call for the support for the Indonesian state and reject any idea of alternative state including that of an Islamic Indonesian state. They both agree that the state and its arrangement and management are non-religious problem. In their appeal to the ummah to support the Indonesian state, they also similarly stress the utility of the Indonesian state for the interest of the ummah. By adding a legal (figh) argument, however, in which the ummah are seen as obligated to support the Indonesian state and to reject any alternative state, Wahid theoretically binds the ummah to the Indonesian state in a more definitive manner. This is in keeping with his idea that being a Muslim is never unsituated to a locality, which can be the state in which he lives. In other words, Wahid's line of argument tends to strengthen the tying and combining of Islam and 
Indonesia as inseparable components that form a basis for identity for an Indonesian Muslim. In Madjid's argument, the link and combination appear more optional.

\section{ISLAM, DEMOCRATIC POLITICS, AND IDENTITY}

Wahid's uncompromising support for the Indonesian national state and rejection of any alternative is in keeping with his view of the state being the framework or order in which politics is to be conducted. Islam, according to Wahid, in inseparable from politics. In order for politics to be able to be conducted in an orderly manner, a legitimate state has to be there functioning as an order and locus for politics. Nahdlatul Ulama, according to Wahid, has declared the Indonesian state as legitimate with Pancasila as its national ideology after laying out the basic criteria for a legitimate state. In so doing, it finalizes the acceptance of the Indonesian state and brought to an end the controversy concerning Pancasila. From this point on, the business of politics can be conducted expediently. We can assume that Madjid agrees with Wahid's idea about the Indonesian state being a framework for politics. This is evident in his arguments for the final acceptance of Pancasila as the state ideology by the ummah and everybody else. Politics, however, seems to mean different things for Wahid and Madjid although they both share the rejection of Islamic power politics. For Wahid, the idea that Islam is inseparable from politics means that the ummah have to organize themselves and engage in politics. The politics, however, is not power politics as such but democratic politics. For Madjid, politics means cultural politics.

This difference will have diverging implications on the idea of identity for the ummah in Indonesia. But first, let me clarify Wahid's democratic politics. Wahid's support for democracy is as unflinching as his support for the Indonesian state. In a nutshell, Wahid's democratic politics is the poltitics for building democracy through social organizing and cultural activities. When he talks about democracy he talks about freedom, justice, and empowerment of the people. He argues, for example, that the main responsibility for a Muslim intellectuals is to alleviate the suffering of men, to join efforts in the eradication of poverty, and to uphold justice. These efforts are carried out by building democratic political structure, by expanding and spreading economic and educational opportunities, and by defending freedom of thought and expression. He suggests that a democratic political structure would include rule of law, equality before the law, and decision making based on majoritarian opinion.

What is of interest here is how Wahid distinguishes between democratic politics and Islamic power politics. The extent to which Wahid adopts the democratic ideas of the Western tradition indicates his unflinching commitment to democracy. For him, commitment to democracy is the ultimate measurement. Things can change but the efforts to build and practice democracy cannot. He believes that Islam contains democratic values, although they might be slumbering now. He is willing to adopt democratic 
values from traditions outside of Islam because he recognizes that they are needed as a catalyst for intellectual development within Islamic tradition. But Islam or otherwise, religious or secular is of no importance for him. What counts is what works for democracy. Religion is a blessing insofar as it works toward the creation of democracy and freedom. Islamic power politics is not imperative for Wahid because it is not a guarantee for democracy. In fact, he views Islamic power politics as an obstacle to democratic politics because of its tendency to prioritize one group over another, to view Islam as a system that is absolutely better than any other, a view that tends to lead to, in Wahid's perspective, exclusivism. He criticizes Muslim groups in Indonesia as tending to monopolize truth leading them to be myopic and narrow-minded. His criticism of practices in the Middle Eastern states sugggests that he thinks that Islamic power politics can be detrimental to democracy. He argues that various Islamic movements in Indonesia will do their best service when they come together under the banner of democracy, to help accumulate, solidify, and mobilize pro-democratic forces. For Wahid, naturally, this democratic politics, while simulteneously disengaged from Islamic power politics, is housed within the Indonesian state. This vision will not eradicate identification with Islam, but will theoretically work toward the fusion of Islamic identity into the Indonesian identity.

Madjid is as committed as Wahid is to democracy and democratic building in Indonesia. He concurs with Wahid in accepting Pancasila as the national ideology that serves as an overarching ideology and binds all peoples of various religions and ideologies, as well as a basis for democracy in Indonesia. He assures non-Muslims, the Christians especially, that Islam is a religion of democracy and human rights. When it comes to the action needed to build democracy, he chooses to adopt the transformation of the people as a strategy. He believes that the best avenue to do this is education. What Madjid has in mind is mainly public education. He assumes that the Indonesian people cannot yet appreciate democracy because they are not adequately informed and educated about democracy. He believes that if they are adequately informed about democracy they will turn democratic and be interested in democratic building.

What are to be taught to the people to make them understand and appreciate democracy? Madjid is fully aware of the strong tradition, with all its shortcomings, of Western democracy. He believes, however, that Islam contains all values a democracy needs. And he thinks that the ummah are not informed enough about this fact. In the meantime, they compose the majority population, a fact that renders their transformation decisive for the process of democratic building in Indonesia. With all these considerations, Madjid seems to have come to a decision to teach the ummah about democracy by teaching them about the democractic treasures contained, but somehow buried, in Islam. He knows that his teaching will be heard by professors of other religions, and believes it will be helpful that they do because they will have a better understanding of Islam and its democratic possibilities. 
Madjid argues that democratic values like justice, freedom, equality, tolerance and democratic civility are all part of basic teachings of Islam. Islam's basic view of man, which, according to Madjid, is shared by other Abrahamic religions, is the idea that man is pure and has an inherent propensity toward the good and the right, hence toward the just. The desire to uphold justice is, then, a core human nature and the will of God, a nature that will lead man toward the prevention of oppression of one man by another. Islam also teaches freedom by setting him free from the bondage to the material world through the worship of a transcendent God. The Islamic view of man as basically good also means that everyone has the same potential to actualize himself as well as to achieve individual enlightenment.

God, however, has not created men to live as separate individuals. He makes them live in groups and races. In fact, God has created men as members of countless races in order for them to come to know one another, to learn, presumably, from one another. Plurality is, then, a will of God. In plurality, it is inevitable that musyawarah is required where deliberation is conducted by observing ethic and civility. In the context of Indonesia, Madjid points out that the idea of musyawarah originated in West Sumatera, the tradition of which is heavily influenced by Islam. Decisions in musyawarah do not always come through consensus (ijma'), but can also come as majority decision. The last was practiced by the prophet himself. Rule of law is also practically a habit to every Muslim with figh being rules that regulates his every conduct on everyday basis. This habit should be able to be transferred and adapted to democratic need without too much trouble.

Madjid further argues that the time of the prophet was not the only time where the Islamic ideal of democracy had been realized. In the $12^{\text {th }}$ century, it was realized again by the khalifs of the Islamic Spain. It was during these time that Islamic community and state truly became the blessing of the whole world, both Islamic and non-Islamic. They constituted a golden age that had inspired Europe with their cosmopolitanism, humanism, scientific inquisitiveness, tolerance toward religious minorities and protection for their rights. Islamic communities today are backward because they failed to hold fast to the teachings of their religion. The ummah in Indonesia, however, can reconstruct this ideal and democratic Islamic community. In Madjid's thinking this is important exactly because the ummah are an overwhelming majority. It is imperative for them to learn about and then work toward the building of democracy. Otherwise, Indonesia's hope for democracy would be dim. Whether or not democracy materializes in the country depends to a great extent on them.

In his concern for democracy in Indonesia, Madjid has high hope for the ummah to play a leading role. He boosts their confidence by trying to convince them that both Islam and themselves have high potential for the project. In fact, in doing so, he greatly emphasizes the superiority of Islam over other religions and traditions. This strategy theoretically tends to encourage the identification of Indonesian democracy with an Islamic democracy. This 
tendency stands out against that which comes out of Wahid's strategy. While Madjid's strategy tends to encourage the fusion of Indonesian identity into the Islamic identity, Wahid's strategy tends to encourage the fusion of Islamic identity into the Indonesian identity.

\section{CONCLUSION}

On a different level, the distinction between the two democratic orders that Wahid and Madjid envision looks similar to the distinction between the democratic orders that the liberals and the communitarians in North America envision respectively. A more careful investigation is needed to confirm this tentative conclusion. But at this point, it seems that Madjid's vision of democracy looks like a religious majoritarian democracy. The north American communitarians, of course, being committed to secularism as Wahid and Madjid are committed to Islam, never theorize about a religious majoritarian democracy. What they have in mind is a cultural majoritarian democracy where the state is permitted to take side with the majority when it comes to the idea of what is good. The state is permitted to support activities and program to promote the majority's idea of what is good insofar as enough protection is accorded to the minorities, enough guarantee is given that no minority rights are taken away. Madjid's vision seems to tend toward this direction where the state is allowed to promote the values of the Muslim majority insofar as enough protection and guarantee for the rights of the minorities are assured. Wahid's vision, on the other hand, looks like that of the liberals. The liberal democracy demands absolute neutrality of the state in the matter of values. The state is not allowed to support any activities or program that promote anyone's values, religious or otherwise. Competition among different value systems, including identity and cultural politics, is given freedom through the political mechanism and process.

I would argue, however, that Wahid is closer to a religious thinker like Roger Wiliams of the seventeenth centrury America than the liberals of the twentieth century America. Wahid is, like Williams was, mainly concerned with keeping the state away from meddling with the religious affairs of the people. And for this purpose, Wahid finds the liberal democratic system, which, by default, is Western in origin, offers a better guarantee than whatever system that the history of Islam and Islamic comunities has to offer.

Madjid and Wahid belong to the same generation. They were born in the same town of Jombang, East Java, Madjid in 1939 and Wahid a year later. They both grew up within the environment of the traditionalist Islam. As they matured, however, they went different ways. Madjid went to the Jakarta State Institute of Islamic Studies (IAIN) and then to Chicago where he wrote his PhD dissertation on Ibnu Taimiyah, a fourteenth century reformist Islamifc thinkers. During his student days, Madjid was active in the Muslim Student Association, a progressive and modernist organization. Since his return from Chicago, Madjid has been active mainly as educator, both in the academy and for the public. Wahid, meanwhile, went to Bagdad for his BA. He travelled 
to Europe and spent some time in universities in France and the Netherlands, but never received any academic degree beyond his BA. As the scion of the founder of Nahdlatul Ulama, Wahid has never been absent from the circle of its contemporary leadership. Needless to say, he became president of the Republic of Indonesia for a year, from 2001 to 2002.

These divergent paths that Madjid and Wahid have followed throws some light, to some extent, on the different ways they think about the relation of Islam and Indonesia and the Indonesian state. Madjid came to be influenced by the issues that have preoccupied the modernist Muslims, that is, the issues of how to raise the Muslim ummah from its contemporary backwardness and to actualize their ideal potentials. Madjid has also been influenced by the modernists, without being puritannical, in that he searches for a model outside the Indonesian history. Wahid, meanwhile, while he works to articulate the relation between Islam and the state and democracy in response to contemporary situation, remains within the paradigm of the traditionalist Islamic movement in Indonesia. The traditionalist Islamic movement in Indonesia rose to stem the tide of the modernist movement. It had to confront the modernist propensity to view the locus of the ideal Islam as situated in the land of Arabia. It also had to confront the puritannical orientation of the modernists that has led them to view local Islamic traditions as impure and, hence, of inferior order. In defense, the traditionalist Muslims have emphasized the worthiness of the Islamic tradition that has grown on the Indonesian soil vis a vis what is viewed by the modernist as the pure Islam. In relying on the former as a basis to formulate his ideas, Wahid, therefore, has followed the steps of his traditionalist prdecessors. These differences between Madjid and Wahid clarifies how the distinction between being a Muslim and an Indonesian in the former's conception of the Indonesian Muslim identity is more pronounced compared with that in the latter's conception.

\section{BIBLIOGRAPHICAL NOTE}

Works on the ideas of Abdurrahman Wahid and Nurcholis Madjid have proliferated in the last several years. For the purpose of disscusing the ideas of these two scholars concerning Islam, the sate, and identity here, however, I have found some earlier works helpful. Greg Barton, in his "The International Context of the Emergence of Islamic Neo Modernism in Indonesia," (in M.C. Ricklefs, ed., Islam in the Indonesian Context, AIA-CSEAS Annual Indonesian Lectures Series No. 15) traces Nurcholis Madjid's neo-modernist ideas to his formative years in the 1970s as well as some Western influences that include ideas of Harvey Cox, Robert N. Bellah, and Talcott Parson. Rober W. Hefner has contributed significantly to the body of writing on both Wahid and Madjid's ideas and activities during the New Order era. Two of his useful pieces are "Islamization and Democratization in Indonesia" (in Robert W. Hefner, and Patricia Horvatich, eds, Islam in an Era of Nation-States: Politics and Religious Renewal in Muslim Southeast Asia, 1997) and "A Muslim Civil Society? Indonesian Reflections on the Conditions of Its Possibility" (in 
Robert W. Hefner ed., Democratic Civility: The History and Cross-Cultural Possibility of a Modern Political Ideal, 1998). In the former, Hefner discusses the role of Madjid in the formation ICMI, and Wahid's position, relative to the possibilities of the role of Islam in the democratic process in Indonesia. In the latter, Hefner briefly touches on the role of Wahid and Madjid in a broad discussion of the possibility of civil society development in Indonesia. Adam Schwarz devotes one chapter in his book, A Nation in Waiting: Indonesia in the 1990s, 1994, to the discussion of Islamic politics during the Suharto era where Wahid plays a prominent role as, being chair of the Nahdlatul Ulama, both thinker and political player, and Madjid, being a figure of ICMI (Indonesian Muslim Intellctual Association), play important role as a thinker. Douglas E. Ramage, meanwhile, in his book Politics in Indonesia: Democracy, Islam and the Ideology of Tolerance, 1995, gives a more comprehensive treatment of the two thinkers' ideas and role in the development of democratic discourses during the era, where topics such as the relationship between Islam and the state and between Islam and democratie development are debated. A brief and specific discussion of Madjid's ideas on democracy and multiculturalism with reference to the Indonesian state ideology can be found in Muhammad Fuad, "American Multiculturalism from an Indonesian perspective" where Madjid's ideas are compared with that of the American black scholar Henry Louis Gates, Jr. and an insightful debate on multiculturalism and its relationship with democracy between liberal and communitarian thinkers in the US and Canada can be found in Amy Gutman, ed. Multiculturalism, 1994, especially in the pieces by Charles Taylor, Júrgen Habermas, and Anthony Appiah.

\section{BIBLIOGRAPHY}

Barton, Greg (1989), “The International Context of the Emergence of Islamic Neo Modernism in Indonesia," in M.C. Ricklefs ed., Islam in the Indonesian Context, Annual Indonesian lectures Series No. 15.

Fuad, Muhammad (1995), "American Multiculturalism from an Indonesian Perspective," Proceedings of the Sixth Symposium on American Studies in the Asia-Pacific Region. Tokyo: International House of Japan.

Gutman, Amy (ed.) (1994), Multiculturalism. Princeton: Princeton Universityy Press.

Hefner, Robert W. (1997), "Islamization and Democratization in Indonesia" in Hefner, Robert and Patricia Horvatich, eds, Islam in an Era of NationStates: Politics and Religious Renewal in Muslim Southeast Asia. Honolulu: University of Hawaii Press.

Hefner, Robert W. (1998), “A Muslim Civil Society? Indonesian Reflections on the Conditions of Its Possibility" in Robert W. Hefner ed, Democratic Civility: The History and Cross-Cultural Possibility of a Modern Political Ideal. New Brunswick and London, Transaction Publishers.

Madjid, Nurcholis (1995), Islam Agama Kemanusiaan: Membangun Tradisi dan Visi Baru Islam Indonesia [Islam, Religion of Humanity: Building Indonesia's New Islamic Tradition and Vision]. Jakarta: Yayasan Wakaf Paramadina. 
Ramage, Douglas E. (1995), Politics in Indonesia: Democracy, Islam and the Ideology of Tolerance. London and New York: Routledge.

Schwarz, Adam (1994), A Nation in Waiting: Indonesia in the 1990s. St. Leonards, NSW, Australia: Allen \& Unwin.

Wahid, Abdurrahman (1999), Mengurai Hubungan Agama dan Negara (Untying the Relationship between Religion and the State). Jakarta: Grasindo. 